\title{
Short Term Follow-up in Patients with Stable Chronic Heart Failure on 5-Phosphodiesterase Inhibitor Sildenafil
}

\author{
MAHMOUD S. ABD EL-MONEUM, M.D. \\ The Department of Cardiology, Faculty of Medicine, Benha University
}

\begin{abstract}
Background: The increased Pulmonary Artery (PA) pressure is due to disturbances in key vascular mediator pathway including relative deficiencies of vasodilators such as Nitric Oxide (NO) and prostacyclins. Vasodilators such as 5phosphodiesterase Inhibitor (sildenafil) are a natural initial therapeutic choice.

Objectives: The study was designed to investigate whether a 50mg twice daily of sildenafil could improve exercise performance, ventilatory efficiency, oxygen uptake kinetics and pulmonary hypertension in patients with stable Chronic Heart Failure (CHF).
\end{abstract}

Methods: Single center, double-blind, placebo-controlled, parallel-group, randomized clinical trial of one hundred patients with stable CHF, Group (A) including fifty patients who received only the standard therapy of CHF (control group), Group (B) including fifty patients who received Sildenafil in addition to standard CHF therapy (active group) for six months. All patients who met screening criteria underwent baseline studies (history and physical examination, cardiopulmonary exercise tests including [peak exercise $\left(\mathrm{VO}_{2}\right.$ peak), ventilatory efficiency (VE/VCO 2 slope) and Recovery Gas Exchange (T1/2VO2min- T1/2VCO2min)] and echocardiography for assessment of mean Pulmonary Artery Pressure (mPAP) and LV systolic function) and were then randomly assigned in a 1:1 ratio, to receive either sildenafil or placebo.

Results: There was statistically significant difference between Group (A) and Group (B), significant improvement in $\mathrm{VO} 2$ peak, $\mathrm{VE} / \mathrm{VCO} 2$ slope, $\mathrm{T}-1 / 2 \mathrm{Vo} 2$ (min), $\mathrm{T}-1 / 2 \mathrm{VCO} 2$ (min) and mean Pulmonary Artery Pressure (mPAP) occurred in Sildenafil group (group B) with $p$-value $<0.05$, while in the control group (group A), there was no significant improvement in all parameters. After using sildenafil in patient with stable CHF for 6 months the mPAP decreased by $20 \%$ in sildenafil group and $2 \%$ in the controlled group. There was also improvement in ventilatory efficiency and exercise performance.

Conclusion: 5-phosphodiesterase Inhibitor (sildenafil) may be benificial as adjunctive therapy for patients with Chronic Heart Faluire (CHF).

Correspondence to: Dr. Mahmoud S. Abd El-Moneum, The Department of Cardiology, Faculty of Medicine, Benha University
Key Words: Sildenafil - Heart failure.

\section{Introduction}

THE goals of treatment in patients with heart failure are to improve their clinical status, functional capacity and quality of life, prevent hospital admission and reduce mortality. The fact that several drugs for HF have shown detrimental effects on long-term outcomes, despite showing beneficial effects on shorter-term surrogate markers, has led regulatory bodies and clinical practice guidelines to seek mortality/morbidity data for approving/ recommending therapeutic interventions for HF. However, it is now recognized that preventing HF hospitalization and improving functional capacity are important benefits to be considered if a mortality excess is ruled out [1]

Multiple mechanisms seem to interfere with exercise performance in CHF, including central (cardiopulmonary) and peripheral (vascular) components. In particular, pulmonary hypertension is an important predictor of functional disabilty in $\mathrm{CHF}$ and may reflect both left ventricular dysfunction and congestion [2]

$\mathrm{PH}$ is defined as an increase in mean Pulmonary Arterial Pressure (mPAP) \.25mmHg at rest as assessed by Right Heart Catheterization (RHC) [3].

Inhibition of the cyclic Guanosine Monophosphate (cGMP) degrading enzyme phosphodiesterase type 5 results in vasodilation through the NO/cGMP pathway at sites expressing this enzyme. Since the pulmonary vasculature contains substantial amounts of phosphodiesterase type 5 , the potential clinical benefit of phosphodiesterase type 5 inhibitors (PDE-5is) has been investigated in PAH. In addition, PDE-5isexert antiproliferative effects [4] . 
The effects of sildenafil have been tested in both the acute and chronic setting in both human and animal studies. Trials assessing the acute effects have primarily focused on the pulmonary and systemic haemodynamics. A recent animal study by Borgdoff and colleagues showed that sildenafil was beneficial in the pressure-loaded right ventricle, with improvements in right ventricular function, wall stress, and exercise tolerance. However, the same effects were not seen in the volume-loaded right ventricle [5].

Phosphodiesterase type 5 inhibitors (PDE5Is) have been shown to have favourable haemodynamic and anti-remodelling effects and to improve exercise capacity and quality of life in patients with CHF. But they are contraindicated in patients taking nitrates [6].

\section{Aim of study:}

This study aimed to investigate whether a 50mg twice daily of Sildenafil could improve exercise performance, ventilatory efficiency, oxygen uptake kinetics and pulmonary hypertension after six months of using it with stable CHF patients.

\section{Material and Methods}

This study had been conducted in Cardiology Department, Faculty of Medicine, Benha University, from February 2016 to September 2017. Included one hundred patients with stable CHF; group (A) including fifty patients who recieved only the standard therapy of CHF (control group), group (B) including fifty patients who recieved Sildenafil in addition to standard CHF therapy (active group) for six months.

\section{Inclusion criteria:}

- Patients with chronic left ventricular systolic dysfunction (EF more than $30 \%$ and less than $50 \%$ ) on standard therapy of CHF [7] .

- Patients with good functional capacity.

- Patients included in this study were more than 20 years of age.

\section{Exclusion criteria:}

- Patient refusal.

- History of intolerance to sildenafil.

- Concomitant use of nitrates.

- Systolic arterial pressure less than $90 \mathrm{mmHg}$.

All patients in this study were subjected to the following:

- Careful history analysis.

- Full clinical examination.
- Baseline 2D-echocardiography study for assessment of mPAP and LV systolic function.

Doppler Echo can approximate Pulmonary Artery Systolic Pressure (PASP) using:

- Tricuspid valve velocity $(4 \mathrm{v} 2=\mathrm{TV}$ pressure gradient).

- Estimated CVP (=RA pressure) [8] .

Bernoulli equation:

- PASP = RVSP (in the absence of RVOTO or pulmonic stenosis).

$-\mathrm{RVSP}=4 \mathrm{v} 2+\mathrm{CVP}$.

- Mean PAP can be approximated because mPAP $=0.610$ PAP $+2[9]$

A systolic PAP of $40 \mathrm{mmHg}$ typically implies a mean PAP more than $25 \mathrm{mmHg}=$ pulmonary hypertension [9].

Severity of pulmonary hypertension (mPAP):

- Mild=25-40mmHg

- Moderate $=41-55 \mathrm{mmHg}$

- Severe $=>55 \mathrm{mmHg}$

- Baseline cardiopulmonary exercise testing for assessment of peak exercise, ventilatory efficiency and recovery gas exchange.

\section{A- Assessment of PASP by Echocardiography:}

Transthoracic echocardiography is used to image the effects of Pulmonary Hypertension (PH) on the heart and estimate PAP from continuous wave Doppler measurements. Echocardiography should always be performed when PH is suspected and may be used to infer a diagnosis of $\mathrm{PH}$ in patients in whom multiple different echocardiographic measurements are consistent with this diagnosis. Detailed guidelines describing the echocardiographic assessment of the right heart can be found in documents created and/or endorsed by the European Association of Cardiovascular Imaging (EACVI) [10].

\section{$B$ - Assessment of Ejection Fraction (EF) by echocardiography:}

For measurement of LVEF, the modified biplane Simpson's rule is recommended. LV End Diastolic Volume (LVEDV) and LV End Systolic Volume (LVESV) are obtained from apical four-and twochamber views. This method relies on accurate tracing of endocardial borders. In case of poor image quality, contrast agents should be used to improve endocardial delineation [11]. 


\section{C- Cardioplumonary exercise testing:}

Cardiopulmonary Exercise Testing (CPX) measures a broader range of variables related to cardiorespiratory function, including expiratory ventilation (VE) and pulmonary gas exchange (oxygen uptake $\left[\mathrm{VO}_{2}\right]$ and carbon dioxide output [ $\left.\mathrm{VCO} 2\right]$ ), along with the ECG and blood pressure, with the goal of quantitatively linking metabolic, cardiovascular, and pulmonary responses to exercise [12]

Maximal $\mathrm{VO}_{2}\left(\mathrm{VO}_{2}\right.$ peak $)$ is an important measurement because it is considered to be the metric that defines the limits of the cardiopulmonary system. It is defined by the Fick equation as the product of cardiac output and arteriovenous oxygen difference $\left[\mathrm{C}(\mathrm{a}-\mathrm{v}) \mathrm{O}_{2}\right]$ at peak exercise:

$$
\begin{aligned}
& \mathrm{VO}_{2} \max =(\mathrm{HR} X \mathrm{SV}) \mathrm{X}\left[\mathrm{C}(\mathrm{a}-\mathrm{v}) \mathrm{O}_{2}\right] \\
& \text { HR: Heart Rate. SV: Stroke Volume. } \\
& \text { C : Content. a : Arterial oxygen. } \\
& \mathrm{v} \text { : Venous oxygen. }
\end{aligned}
$$

Ventilatory efficiency can be assessed by evaluation of the rise in minute Ventilation (VE) relative to work rate, $\mathrm{VO}_{2}$, or $\mathrm{VCO} 2$. The most widely studied index of ventilatory efficiency is the VE/ $\mathrm{VCO} 2$ slope [13].

\section{Statistical analysis:}

The data was analyzed using statistical program for social science (SPSS) Version 19.0.

- Descriptive statistics were done including mean, standard deviation and prevalence.

- Chi-square test was done to find out the presence of significant difference between the two groups regarding the non-parametric variables.

- $p$-values $<0.05$ were considered statistically significant.

\section{Results}

This study included one hundred patients with stable CHF; group (A) including fifty patients who received only the standard therapy of CHF (control group), group (B) including fifty patients who received Sildenafil in addition to standard CHF therapy (active group) for six months.

The mean age in group (A) was $54 \pm 18$ years and in group (B) was $49 \pm 16$ years. There was no statistically difference between group (A) and group (B) with regard to age ( $p$-value $>0.05$ ).

In this study there were 66 male $(66 \%)$ and 34 female (34\%). There was no statistically difference between group (A) and group (B) with regard to gender with $p$-value $>0.05$.

In current study there were 43 hypertensive patients (43\%), 56 diabetic patients (56\%), 53 patients were current smokers $(53 \%)$ and dyslipedemia presented in 65 patients $(65 \%)$. There was no statistically difference between group (A) and group (B) with $p$-value $>0.05$.

\section{Sildenafil effect on $m P A P$ :}

In Table (1): The mPAP classified into mild $(25-40 \mathrm{mmHg})$, moderate $(41-55 \mathrm{mmHg})$ and severe $(>55 \mathrm{mmHg}$ ) pulmonary HTN. In Sildenafil group (group B), there were 30 patients with moderate pulmonary HTN $(41-55 \mathrm{mmHg}$ ) and 20 patients with severe pulmonary HTN $(>55 \mathrm{mmHg}$ ), after receiving Sildenafil, the pulmonary HTN improved from (moderate to severe) pulmonary HTN to mild pulmonary HTN in 10 patients which was of statistically significant difference with $p$-value $<0.05$.

While in control group (group A), there were 33 patients with moderate pulmonary HTN (41$55 \mathrm{mmHg}$ ) and 17 patients with severe pulmonary HTN $(>55 \mathrm{mmHg}$ ), improvement was only in one patient with $p$-value $>0.05$.

\section{Sildenafil effect on EF of $L V$ :}

In Table (2): As regard LV ejection fraction, there was no statistically significant decrease in EF in both active and control groups with $p$-value $>0.05$.

Effect of Sildenafil and placebo on cardiopulmonay exercise test parameters:

In Table (3): Regarding Sildenafil group, there was a significant improvement in peak exercise $\left(\mathrm{VO}_{2}\right.$ peak), Ventilatory Efficiency (VE/VCO 2 slope) and Recovery Gas Exchange ( $\mathrm{T} 1 / 2 \mathrm{VO}_{2} \mathrm{~min}-$ $\mathrm{T} 1 / 2 \mathrm{VCO}_{2} \mathrm{~min}$ ) occurred with $p$-value $<0.05$. While in the control group there were no significant improvement in all pareameters with $p$-value $>0.05$.

Table (1): mPAP by ECHO before and after treatment in the studied groups.

\begin{tabular}{lllllll}
\hline \multirow{2}{*}{ Groups } & mPAP & \multicolumn{2}{l}{ Before treatment } & \multicolumn{2}{c}{ After treatment } & \multirow{2}{*}{$\begin{array}{c}p \text { - } \\
\text { value }\end{array}$} \\
\cline { 3 - 6 } & mmHg & No & $p$ & No & $p$ & \\
\hline Group A & $25-40$ & & & 1 & $2 \%$ & NS \\
& $41-55$ & 33 & $66 \%$ & 32 & $64 \%$ & \\
& $>55$ & 17 & $34 \%$ & 17 & $34 \%$ & \\
Group B & $25-40$ & & & 10 & $20 \%$ & $<0.05^{*}$ \\
& $41-55$ & 30 & $40 \%$ & 24 & $48 \%$ & \\
& $>55$ & 20 & $60 \%$ & 16 & $32 \%$ & \\
\hline
\end{tabular}

Data are presented number (percent).

NO : Number.

$p \quad$ : Percent

$p_{\text {mPAP }}$ : Mean Pulmonary Artery Pressure. 
Table (2): Ejection Fraction (EF) after six months in studied groups.

\begin{tabular}{lccc}
\hline & \multicolumn{2}{c}{ Ejection Fraction (EF\%) } & $p$ - \\
\cline { 2 - 3 } Groups & $\begin{array}{c}\text { Before treatment } \\
\text { Mean } \pm \text { SD }\end{array}$ & $\begin{array}{c}\text { After treatment } \\
\text { Mean } \pm \text { SD }\end{array}$ & value \\
\hline Group A & $39 \pm 1 \%$ & $38.4 \pm 5 \%$ & NS \\
Group B & $40 \pm 1 \%$ & $38.0 \pm 2 \%$ & NS \\
\hline
\end{tabular}

Data are presented as mean $\pm \mathrm{SD}$ or number (percent).

Table (3): Cardiopulmonay exercise test parameters.

\begin{tabular}{|c|c|c|c|c|c|c|}
\hline & \multicolumn{2}{|c|}{ Control group } & \multirow[b]{2}{*}{$\begin{array}{c}p- \\
\text { value }\end{array}$} & \multicolumn{2}{|c|}{ Sildenafil group } & \multirow[b]{2}{*}{$\begin{array}{c}p- \\
\text { value }\end{array}$} \\
\hline & $\begin{array}{l}\text { Before } \\
\text { Mean } \\
\pm \mathrm{SD}\end{array}$ & $\begin{array}{l}\text { After } \\
\text { Mean } \\
\pm \mathrm{SD}\end{array}$ & & $\begin{array}{l}\text { Before } \\
\text { Mean } \\
\pm S D\end{array}$ & $\begin{array}{l}\text { After } \\
\text { Mean } \\
\pm \mathrm{SD}\end{array}$ & \\
\hline $\begin{array}{l}\text { - Peak exercise } \\
\text { (VCO2). }\end{array}$ & $16.4 \pm 3$ & $17 \pm 2$ & NS & $17.2 \pm 2$ & $20 \pm 2.5$ & $<0.05 *$ \\
\hline $\begin{array}{l}\text { - Ventilatory } \\
\text { efficiency (VE/ } \\
\text { VCO2 slope). }\end{array}$ & $44.7 \pm 6$ & $44.9 \pm 6$ & NS & $39.1 \pm 6$ & $42.1 \pm 5$ & $<0.05 *$ \\
\hline \multicolumn{7}{|l|}{$\begin{array}{l}\text { Recovery gas } \\
\text { exchange: }\end{array}$} \\
\hline (T1/2VO2min) & $2.6 \pm 0.7$ & $2.7 \pm 1$ & NS & $2.3 \pm 0.5$ & $2.3 \pm 0.5$ & $<0.05^{*}$ \\
\hline (T1/2VCO2min) & $2.5 \pm 1$ & $2.6 \pm 0.9$ & NS & $2.0 \pm 0.4$ & $1.8 \pm 0.2$ & $<0.05^{*}$ \\
\hline
\end{tabular}

\section{Discussion}

Pulmonary Hypertension (PH) is a pathophysiological disorder that may involve multiple clinical conditions and can complicate the majority of cardiovascular and respiratory diseases [14].

Available data have shown that the normal $\mathrm{mPAP}$ at rest is $14 \pm 3 \mathrm{mmHg}$ with an upper limit of normal of approximately $20 \mathrm{mmHg}$. The clinical significance of a mPAP between 21 and $24 \mathrm{mmHg}$ is unclear. Patients presenting with a Pulmonary Artery Pressure (PAP) in this range should be carefully followed when they are at risk for developing PAH [15].

The aim of our study is to investigate whether a 50mg twice daily of sildenafil could improve exercise performance, ventilatory efficiency and lowering mPAP in patients with stable chronic heart failure.

The current study was conducted in Benha University Hospital, Cardiology Department. The study included one hundred patients with stable $\mathrm{CHF}$; group (A) including fifty patients who received only the standard therapy of CHF (control group), group (B) including fifty patients who received Sildenafil in addition to standard CHF therapy (active group).
In the current study, some patients reported side effects from Sildenafil in the form of flushing in 4 patients, headache in 2 patients and diarrhea in 1 patient however these side effects did not interrupt treatment.

Regarding assessment of mPAP by echocardiography after six months in the studied groups the mPAP improved in $20 \%$ of patients in Sildenafil group (group B) while improvement was only $2 \%$ in control group (group A) which was of statistically significant difference with $p$-value $<0.05$. This supported by the results of Chockalingam et al., who reported a decrease in mPAP (up to $25 \%$ ) with Sildenafil 50mg b.i.d at 4 weeks [16].

As regard the study of cardiopulmonary function test, patients were assessed after Sildenafil intake and significant improvement in peak exercise, ventilatory effeciency and recovery gase exchange, this was in concordance with Wong et al., who reported significant improvement in these parameters after adding Sildenafil 50mg twice daily for 4 months [17].

\section{Study limitation:}

This was a single center study, and it is possible that unique charactristics of patients, the physicians or the institution may limit the generalizability of these results.

The number of patiens in this study was relatively small 100 patients. Also, follow-up period was relatively short (six months) in comparison with other studies in which a larger number of patients were enrolled and longer follow-up period.

\section{Conclusion:}

5-phosphodiesterase Inhibitor (sildenafil) may be benificial as adjunctive therapy for patients with Chronic Heart Faluire (CHF).

\section{References}

1- AMBROSY A.P., FONAROW G.C., BUTLER J., CHIONCEL O., GREENE S.J., VADUGANATHAN M. NODARI S., et al.: The global health and economic burden of hospitalizations for heart failure. J. Am. Coll. Cardiol., 63: 1123-33, 2014.

2- MORAES D.L., COLUCCI W.S. and M.M. GIVERTZ: Secondary pulmonary hypertension in chronic heart failure: The role of the endothelium in pathophysiology and management Circulation, 102: pp. 1718-23, 2000.

3- HOEPER M.M., BOGAARD H.J., CONDLIFFE R., FRANTZ R., KHANNA D., KURZYNA M., LANGLEBEN D., et al.: Definitions and diagnosis of pulmonary hypertension. J. Am. Coll. Cardiol., 62 (Suppl): D42D50, 2013. 
4- NAZZARENO G., MARC H., JEAN-LUC V., SIMON G., IRENE L., ADAM T., et al.: 2015 ESC/ERS Guidelines for the diagnosis and treatment of pulmonary hypertension. European Heart Journal (2016) 37: 67-119, 2015.

5- BORGDORFF M.A.J., BARTELDS B., DICKINSON M.G., BOERSMA B., WEIJ M., et al.: Sildenafil enhances systolic adaptation, but does not prevent diastolic dysfunction, in the pressure-loaded right ventricle Eur. J. Heart Fail., 14: 1067-74, 2015.

6- GIANNETTA E., FEOLA T., GIANFRILLI D., POfi R., DALL'ARMI V., et al.: Is chronic inhibition of phosphodiesterase type 5 cardioprotective and safe? A meta-analysis of randomized controlled trials. B.M.C. Med., 12: 185, 2014.

7- PIOTR P., ADRIAAN A.V., STEFAN D. ANKER, HÉCTOR B., JOHN G.F., ANDREW J.S., et al.: 2016 ESC Guidelines for the diagnosis and treatment of acute and chronic heart failure: The Task Force for the diagnosis and treatment of acute and chronic heart failure of the European Society of Cardiology (ESC). European Heart Journal, Volume 37, Issue 27, 14 July 2016, Pages 2129. 200, 2016.

8- RUDSKI L.G., et al.: Guidelines for the echocardiographic assessment of the right heart in adults: a report from the American Society of Echocardiography. J. Am. Soc Echocardiogr., 2010 Jul., 23 (7): 687-8, 691-2, 698-9, 2010.

9- SATHISH P., SEAMUS W., BRODIE L.L., NICHOLAS D.G., et al.: Assessment of pulmonary artery pressure by echocardiography A comprehensive review Int. J. Cardiol. Heart Vasc., Sep., 12: 45-51, 2016.

10- LANG R.M., BADANO L.P., MOR-AVI V., AfiLALO J., ARMSTRONG A., ERNANDE L., et al.: Recommendations for cardiac chamber quantification by echocardiography in adults: An update from the American Society of Echocardiography and the European Association of Car- diovascular Imaging. Eur. Heart J. Cardiovasc. Imaging, 16: 233-71, 2015 .

11- LANG R.M., BADANO L.P., MOR-AVI V., AfiLALO J., ARMSTRONG A., ERNANDE L., FLACHSKAMPF F.A., FOSTER E., GOLDSTEIN S.A., et al.: Recommendations for cardiac chamber quantification by echocardiography in adults: An update from the American Society of Echocardiography and the European Association of Cardiovascular Imaging. Eur. Heart J. Cardiovasc. Imaging;16: 233-70, 2015.

12- BALADY G., ARENA R., SIETSEMA K.E., MYERS J., COKE L., FLETCHER G.F., et al.: American Heart Association scientific statement: A clinician's guide to cardiopulmonary exercise testing in adults. Circulation., 122: 191-225, 2010.

13- GARY J.B., ROSS A., KATHY S., JONATHAN M., LOLA C., et al.: Clinician's Guide to Cardiopulmonary Exercise Testing in Adults. A Scientific Statement From the American Heart Association Circulation, 122: 191225,2010

14- NAZZARENO G., MARC H., JEAN-LUC V., SIMON G., IRENE L., ADAM T., et al.: ESC/ERS Guidelines for the diagnosis and treatment of pulmonary hypertension. European Heart Journal, 37: 67-119, 2016.

15- HOEPER M.M., BOGAARD H.J., CONDLIFFE R., FRANTZ R., KHANNA D., KURZYNA M., et al.: Definitions and diagnosis of pulmonary hypertension. $\mathrm{J}$. Am. Coll. Cardiol., 62 (Suppl): D42-D50, 2013.

16- CHOCKALINGAM A., GNANAVELU G., VENKATESAN S., et al.: Efficacy and optimal dose of sildenafil in primary pulmonary hypertension Int. J. Cardiol., 99 (1): pp. 91-5, 2005.

17- WONG R.C., KOH G.M., CHOONG P.H. and YIP W.L.: Oral sildenafil therapy improves health-related quality of life and functional status in pulmonary arterial hypertension Int. J. Cardiol., p. 23, 2006. 


\section{متابعة قصيرة الآجل لتآثير عقار السيلدينافيل

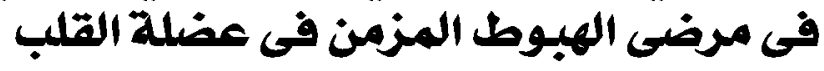

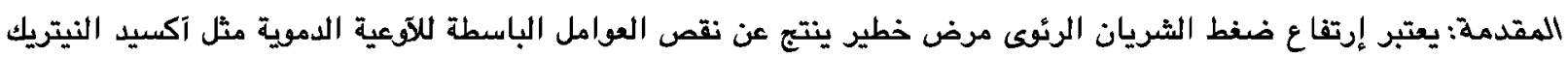

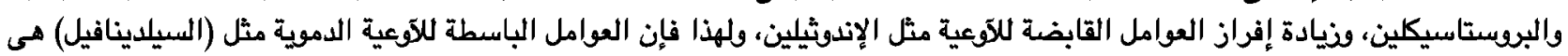

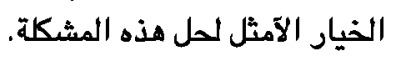

الهدف من العمل: صممت الدراسة للتحقيق فى ما إذا كان ( •مملغ مرتين يوميا) من عقار السيلدينافيل (الفياجرا) يمكن آن يحسن آداء

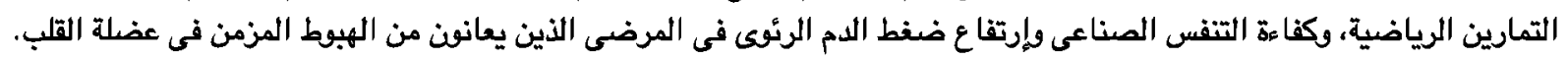

الآساليب: إثتملت الدراسة على (. (1) مريض يعانون من هبوط مزمن فى عضلة القلب. المجموعة (آ) وتشمل (.0) مريضا ممن تلقوا

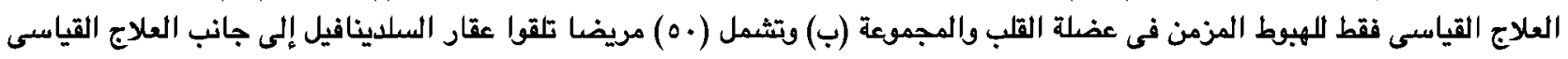
للقلب.

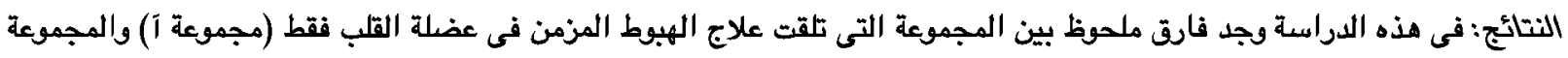

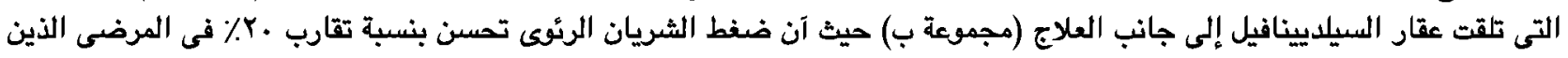

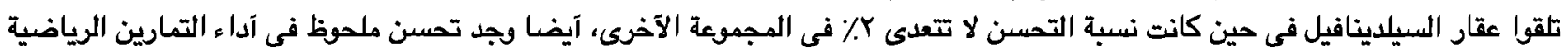

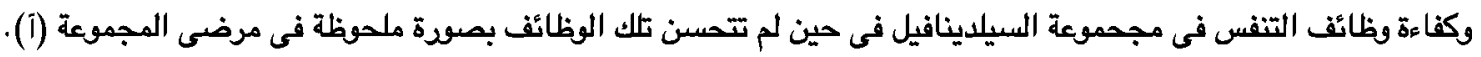

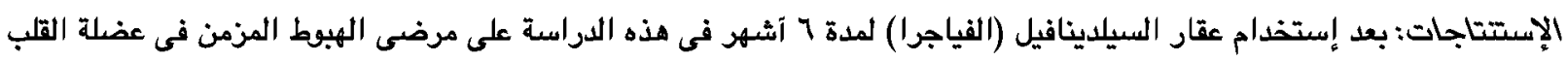

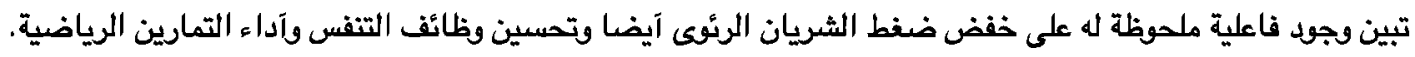

